\title{
Assimilation and Toxicity of Exogenous Amino Acids in the Methane-oxidizing Bacterium Methylococcus capsulatus
}

\author{
By M. ECCLESTON AND D. P. KELLY \\ Department of Microbiology, Queen Elizabeth College, \\ Campden Hill, London, $W 87 \mathrm{AH}$
}

(Accepted for publication 2 March 1972)

\begin{abstract}
SUMMARY
Of $2 \mathrm{I}$ amino acids tested, only L- and D-threonine, L-phenylalanine, L-histidine, L-tyrosine and L-homoserine inhibited exponential growth of Methylococcus capsulatus at $\mathrm{I} \cdot 0 \mathrm{mM}$. Inhibition by L-threonine was relieved by L-methionine, L-homoserine, L-alanine and L-valine, but not by L-lysine, 2,6-diaminopimelic acid or L-arginine. ${ }^{14} \mathrm{C}$-labelled methane, L-aspartate, L-threonine, L-homoserine, L-glutamic acid, L-phenylalanine and L-tryptophan were all assimilated. The results suggested that the branched pathway for threonine, isoleucine, methionine and lysine synthesis from aspartate is functional. An explanation of threonine-inhibition in terms of an interference with end-product regulation of this pathway is proposed.
\end{abstract}

\section{INTRODUCTION}

Methylococcus capsulatus is an obligate methylotroph, capable of aerobic growth only on methane, methanol or dimethyl ether as carbon substrates in an otherwise inorganic medium (Foster \& Davis, 1966; Patel \& Hoare, 197I; Wilkinson, 197I). It obtains energy from the oxidation of these compounds to carbon dioxide, and obtains most of its carbon from the fixation of formaldehyde (an intermediate of the oxidation pathway) by condensation with a pentose phosphate as the first reaction of a cyclic mechanism resembling the Calvin cycle of autotrophs (Kemp \& Quayle, I966; Quayle, I969; Lawrence, Kemp \& Quayle, I970; Kemp, I972). Methylococcus capsulatus cannot grow heterotrophically on any other organic substrate. Obligate methylotrophs thus exhibit a metabolic fastidiousness paralleling that of the obligate chemolithotrophs. Both types of organisms seem able to use only a few special substrates for energy supply; both depend on special mechanisms for the assimilation of oxidized $\mathrm{C}_{1}$-compounds; and in a number of cases have an incomplete tricarboxylic acid cycle, lacking $\alpha$-oxoglutarate dehydrogenase (Smith, London \& Stanier, I967; Patel, Hoare \& Taylor, 1969; Rittenberg, 1969; Aleem, 1970; Kelly, I971). The metabolic relationship of methylotrophs to autotrophs and heterotrophs was discussed recently, and one may regard the methylotrophs as specialized heterotrophs or perhaps better as members of a mixed group of 'autotrophic' organisms dependent on $\mathrm{C}_{1}$-compounds (Ribbons, Harrison \& Wadzinski, I970; Kelly, 197I; Wilkinson, 1971).

The reaction of Methylococcus capsulatus to organic compounds containing two or more carbon atoms has not been extensively reported. Some paraffins and alcohols are oxidized, but do not support growth (Foster \& Davis, 1966; Patel \& Hoare, I97I); some amino acids may be used as sources of nitrogen (Patel \& Hoare, 197I); and acetate and formate can be assimilated during growth on methane (M. Eccleston \& D. P. Kelly, unpublished; Patel et al. 1969). Work in this Department showed inhibition of growth of $M$. capsulatus in plate 
culture by several organic compounds (Eroshin, Harwood \& Pirt, I968). Inhibition of growth of some obligate chemolithotrophs by exogenous amino acids has recently been shown to result from the inhibitory effects of these amino acids on branched biosynthetic pathways for amino acids (Kelly, I969c, I97I; Johnson \& Vishniac, I970; Lu, Matin \& Rittenberg, 197I).

Interest in the metabolic basis for the response of obligate methylotrophs to organic matter and consideration of their current industrial importance as sources of protein and possibly free amino acids from methane led us to investigate amino acid metabolism in Methylococcus capsulatus. This paper reports tracer studies on pathways for amino acid synthesis by $M$. capsulatus, and studies on the kinetics and relief of growth inhibition by amino acids.

\section{METHODS}

Organism. We used the strain of Methylococcus capsulatus (Foster \& Davis, I966) previously used in this Department by Eroshin et al. (1968).

Medium. The organism was grown on the medium of Eroshin et al. (1968), with the following modifications to parts $\mathrm{A}$ and $\mathrm{B}$, which now contained $(\mathrm{g} / \mathrm{l})$ after mixing: part $\mathrm{A}-\mathrm{Na}_{2} \mathrm{HPO}_{4}, \mathrm{I} \cdot 9 ; \mathrm{KH}_{2} \mathrm{PO}_{4}, 0.8 ;$ part B $-\mathrm{MgSO}_{4} .7 \mathrm{H}_{2} \mathrm{O}, 0.8 ; \mathrm{NaCl}, 0.05 ; \mathrm{NH}_{4} \mathrm{Cl}, \mathrm{I} \cdot 0$. The final $\mathrm{pH}$ was $6 \cdot 8$. The increased phosphate concentration provided a convenient method for increasing the cell yield (by keeping the $\mathrm{pH}$ stable for longer periods) and for increasing the length of the lag phase prior to exponential growth, without affecting the growth rate. The increased lag enabled us to set up cultures on the day before an experiment, so that cells were in the early logarithmic phase and ready for use the following morning. (Growth was possible on even higher phosphate concentrations and gave even higher cell yields, but at the expense of a slower growth rate and an extended lag period.)

Nitrogen source. Since Methylococcus capsulatus uses either nitrate or ammonium ion, experiments were carried out to determine the best nitrogen source. $\mathrm{NH}_{4} \mathrm{Cl}$ over the range 0.05 to $0.15 \%(\mathrm{w} / \mathrm{v})$ resulted in good growth rates and maximum biomass using the high phosphate concentration (part A), but when cultures were inadequately buffered growth was accompanied by a rapid drop in $\mathrm{pH}$, until growth eventually ceased at $\mathrm{pH} 4 \cdot 0 . \mathrm{NH}_{4} \mathrm{Cl}$ at $0.2 \%(\mathrm{w} / \mathrm{v})$ produced a longer lag period and reduced the growth rate. Higher concentrations were not tested, but previous work in this Department (T. Thomas, unpublished data) demonstrated inhibition at $0.3 \%$ and $0.6 \%(\mathrm{w} / \mathrm{v})$ possibly by competitive inhibition of methane oxidase (Whittenbury, Phillips \& Wilkinson, I970). In contrast, $\mathrm{NaNO}_{3}$ provided a stabilized $\mathrm{pH}$ (after an initial rise from 6.8 to $7 \cdot 4$ ), but growth rates and yields were lower, which might be predicted from energy considerations. Further, growth on nitrate was always preceded by an extended lag period (inoculum cultures were grown up in the presence of low concentrations of $\mathrm{NO}_{3}^{-}$or $\mathrm{NH}_{4}^{+}$as appropriate before experimentation). Experiments in which the organism was grown on nitrogen-limiting mixtures of $\mathrm{NaNO}_{3}$ plus $\mathrm{NH}_{4} \mathrm{Cl}$ suggested a preference for $\mathrm{NH}_{4}^{+}$. Diauxic growth curves were obtained indicating an initial rapid growth on $\mathrm{NH}_{4}^{+}$, followed after $\mathrm{NH}_{4}^{+}$exhaustion by a stationary phase, leading to resumed growth at a much slower rate on $\mathrm{NO}_{3}^{-}$. Our conclusions support those reported independently by workers at Edinburgh (Whittenbury et al. 1970), but the experimental data suggest both a preference for and a considerable tolerance to ammonium ions by our strain. $\mathrm{NH}_{4} \mathrm{Cl}(\mathrm{O} \cdot \mathrm{I} \%$, w/v) was therefore used routinely in the following experiments as the nitrogen source.

Growth on ${ }^{35} \mathrm{SO}_{4}^{2-}$. For growth on ${ }^{35} \mathrm{SO}_{4}^{2-}$, part $\mathrm{B}$ of the basic medium was modified to contain (g/l) after mixing: $\mathrm{Na}_{2}{ }^{35} \mathrm{SO}_{4}$ (specific activity $0.28 \mathrm{mCi} / \mathrm{mM}$ ), $0.46 ; \mathrm{MgCl}_{2} \cdot 6 \mathrm{H}_{2} \mathrm{O}$, $0 \cdot 26 ; \mathrm{NH}_{4} \mathrm{Cl}, \mathrm{I} \cdot 0$. 
Culture conditions. Cultures were grown in nephlos flasks (Erlenmeyer flasks fitted with test-tube side-arms), which could be inserted into a colorimeter. Flasks were fitted with sterile rubber bungs with two outlet ports. One port was fitted with a rubber vaccine cap (Suba Seal) for sampling, and the other with a plug of cotton-wool through which ingoing gases were sterilized. A graduated $250 \mathrm{ml}$ tap funnel inverted over a beaker of water served as a convenient system for gassing the flasks. Methane (90\% sewage methane; $10 \%$ carbon dioxide, $v / v$ ) was run through the water into the funnel reservoir. The gassing port of the flask was connected by rubber tubing and a glass-tubing T-piece to the stem of the tap funnel, and to a vacuum line fitted with pressure gauge. The flask was partially evacuated, and by slowly opening the tap of the tap funnel a known volume of methane was run into the flask. Atmospheric pressure was automatically restored in the flask by any ingoing air on disconnecting from the apparatus. The gassing port was sealed after gassing by means of a second Suba seal.

All flasks (total volume $337 \mathrm{ml}$ ) contained Io $\mathrm{ml}$ of culture, and initially contained an atmosphere of $29 \% \mathrm{CH}_{4}, 3 \% \mathrm{CO}_{2}$ and $68 \%$ air, v/v.

Culture maintenance. Cultures were routinely maintained in liquid medium by subculturing once every 7 days, using a $20 \%(\mathrm{v} / \mathrm{v})$ inoculum. Strict aseptic precautions were essential, all inoculating being carried out in a 'sterile' laminar-flow cabinet. Cultures were frequently tested for contaminants by streaking on to nutrient agar on which Methylococcus cannot grow. Cultures were also checked microscopically. All experimental and stock cultures were incubated at $37^{\circ} \mathrm{C}$, and aerated by rotation at $200 \mathrm{rev} . / \mathrm{min}$.

Growth experiments. All experiments were started by inoculating $\mathrm{I} \mathrm{ml}$ of a $24 \mathrm{~h}$ culture into $8 \mathrm{ml}$ of medium. Growth was followed by optical density measurements using an EEL colorimeter (model A, 404 filter) which was previously calibrated for the conversion of optical density (EEL units) into dry weight of cells. On reaching the optical density of $r \cdot 00$ $(0.31 \mathrm{mg}$ dry wt bacteria/ml) cells were in the early exponential phase of growth, and $\mathrm{I} \mathrm{ml}$ of the test compound was injected into the culture, bringing the final culture volume to Io $\mathrm{ml}$. Controls were provided in which water replaced the test compound. Optical density readings were then recorded for a further 6 to $\mathrm{I} 2 \mathrm{~h}$. When ${ }^{14} \mathrm{CH}_{4}$ was used a regassing procedure was used: flasks were partially evacuated, ${ }^{14} \mathrm{CH}_{4}$ introduced with a syringe, and the ordinary $\mathrm{CH}_{4} / \mathrm{CO}_{2}$ mixture then added by the normal procedure.

Amino acids were tested for their ability to reverse the inhibitory effects of threonine either by the addition of both threonine and test acid at the standard optical density $(\mathrm{I} \cdot \mathrm{O})$, or by adding only the threonine (in $0.5 \mathrm{ml}$ ) at this point to obtain growth inhibition, followed by addition of the test compound (in $0.5 \mathrm{ml}$ ) $4 \mathrm{~h}$ later. In all inhibition-reversal experiments the inhibitor and test acids were supplied to give a final concentration of $\mathrm{I}$ mM.

Incorporation of labelled amino acids. Incorporation of ${ }^{14} \mathrm{C}$ from isotopically labelled amino acids by exponentially growing cultures was determined after removing $0.2 \mathrm{ml}$ samples from cultures with sterile syringes and mixing with equal volumes of $10 \%(\mathrm{w} / \mathrm{v})$ trichloracetic acid. After standing at $3^{\circ} \mathrm{C}$ for $30 \mathrm{~min}$, the samples were filtered through Millipore HA membranes $(0.45 \mu \mathrm{m}$ pore size), which were then washed with distilled water, dried, and placed in scintillation vials for counting. Rates of amino acid incorporation during growth were expressed as $\mathrm{nmol} / \mathrm{mg}$ increase in bacterial dry $\mathrm{wt} / \mathrm{ml}$, irrespective of time (Kelly, I969 $b$ ).

Fractionation of organisms after ${ }^{14} \mathrm{C}$ incorporation was based on the procedures of Roberts et al. (1955) as were the methods for hydrolysis of protein and nucleic acid fractions and their subsequent preparation for chromatography (Kelly, I967). In some cases hydrolysed proteins were oxidized with $\mathrm{H}_{2} \mathrm{O}_{2}$ prior to chromatography (Smith, 1960). Fractiona- 
tions were carried out using 8 to $\mathrm{I} 2 \mathrm{mg}$ dry wt of cells, and the results represent the average of at least two determinations.

Chromatography. Amino acids were separated by ascending paper chromatography, using Whatman no. I, Io in ${ }^{2}$ papers, run in the first dimension with $n$-butanol + glacial acetic acid + water (I2:3:5 by vol.); second dimension with $80 \%(\mathrm{w} / \mathrm{v})$ aqueous phenol, containing $0.5 \%(\mathrm{w} / \mathrm{v}) 0.880$ ammonia solution (Smith, I960).

A culture supernate, after growth on $\left[{ }^{14} \mathrm{C}\right]$ aspartate was analysed by ascending chromatography on Whatman no. I paper with $n$-butanol + pyridine + water (I:I:I) (Smith, I960). After chromatography, amino acids were detected by dipping in a solution of $0.2 \%(\mathrm{w} / \mathrm{v})$ ninhydrin in acetone containing a small amount of aqueous pyridine (Smith, 1960), and heating the dry paper at $105^{\circ} \mathrm{C}$. Radioactive areas on chromatograms were located by autoradiography, using Kodirex X-ray films (Kelly, 1967). Ninhydrin was not applied to papers prior to quantitative ${ }^{14} \mathrm{C}$ assay.

Nucleic acid bases were separated by a single descending run on Whatman no. I paper using the following solvent: iso-propanol + conc. $\mathrm{HCl}+$ water (130:37:200 by vol.). Purines and pyrimidines were detected by u.v. light $(254 \mathrm{~nm}) .{ }^{14} \mathrm{C}$ regions on the one-dimensional strip chromatograms were located by means of a Packard Radiochromatogram Scanner (Model $720 \mathrm{I}$ ), using a flowing gas mixture of $\mathrm{I} \cdot 3 \%$ butane with $98 \cdot 7 \%$ helium.

\section{Estimation of ${ }^{14} \mathrm{C}$ in labelled material}

(i) Radioactivity of cells on Millipore membranes was determined by liquid scintillation counting at $-8^{\circ} \mathrm{C}$ in a Packard Model 3003 Tri-Carb Liquid Scintillation Spectrometer. The scintillation mixture was $3 \mathrm{ml}$ of $0.8 \%$ (w/v) 2,5 -bis $\left(5^{\prime}\right.$-t-butyl benzoxalolyl[2']) thiopene (BBOT) in 'AnalaR' toluene. Counting efficiency was 80 to $90 \%$.

(ii) Samples from cell fractionation were dried on to $I$ in. diameter steel planchets and counted by means of a Geiger-Müller tube in a lead castle (Isotope Developments Ltd, Aldermaston, Berkshire) linked to an automatic scaler (Type N 530F, Ekco Electronics Ltd, Southend, Essex). The total ${ }^{14} \mathrm{C}$ recovered in the various fractions was 80 to $90 \%$ of that incorporated into whole bacteria. The hot TCA-insoluble (protein) fraction was counted before hydrolysis; recoveries were Io to I $5 \%$ lower if the protein was counted after hydrolysis.

(iii) Samples obtained by partition of the $70 \%$ ethanol fraction with ether were dried on to fibre-glass discs for scintillation counting (Davies \& Cocking, 1966; Kelly, 1967), and counted using $3 \mathrm{ml}$ of $0.8 \%$ BBOT.

(iv) Spots cut from paper chromatograms were assayed by liquid scintillation counting (Kelly, 1967 ) in $20 \mathrm{ml}$ of $0.8 \%$ BBOT.

Chemicals. Radiochemicals were purchased from the Radiochemical Centre, Amersham, Buckinghamshire. The methane-carbon dioxide gas mixture was from Air Products Ltd, London. D-Threonine and L-homoserine were Sigma products, and 2,6-diaminopimelic acid was from Koch-Light Ltd, Colnbrook, Buckinghamshire. Other amino acids were Mann products. BBOT was from CIBA, Horsham, Sussex. All other chemicals were of analar grade, from British Drug Houses, Poole, Dorset or Hopkin \& Williams, Romford, Essex.

\section{RESULTS}

Growth inhibition by amino acids. Of the common amino acids tested, glycine, D-phenylalanine, and the $\mathrm{L}$ isomers of methionine, lysine, proline, arginine, serine, alanine, leucine, isoleucine, tryptophan, cysteine, valine, aspartic acid and glutamic acid (each at $\mathrm{I} \cdot 0 \mathrm{mM}$ ) had no effect on the exponential growth rate of Methylococcus capsulatus. L- and D-Threonine 
Table I. Amino acids toxic at $\mathrm{I} \mathrm{mM}$

Test acids were added to exponentially growing cultures on reaching a cell density of $0.31 \mathrm{mg}$ dry wt bacteria/ml. Growth was then recorded for 8 to $10 \mathrm{~h}$.

Amino acid

Percentage inhibition (\% reduction of growth rate relative to control)

L-Phenylalanine

79

L-Threonine 85

D-Threonine

L-Histidine

L-Tyrosine IOO after 5 to $7 \mathrm{~h}$ (see text)

L-Homoserine Ioo after 8 to $9 \mathrm{~h}$ (see text) 47

38

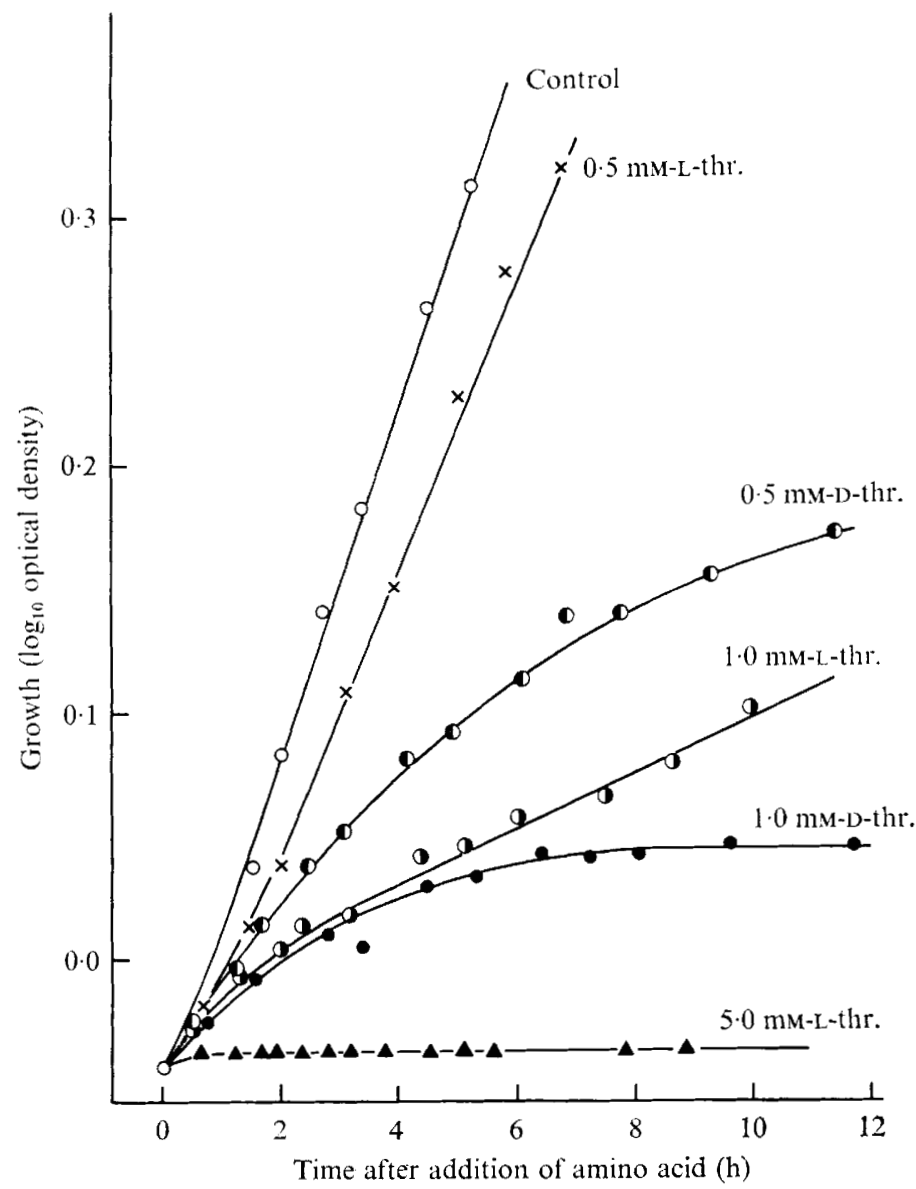

Fig. I. Effect of several concentrations of L-threonine and D-threonine on the growth of Methylococcus capsulatus. L-Threonine or D-threonine was added to exponentially growing cultures on reaching a cell density of $0.31 \mathrm{mg}$ dry wt cells $/ \mathrm{ml}$. The control received only water. 


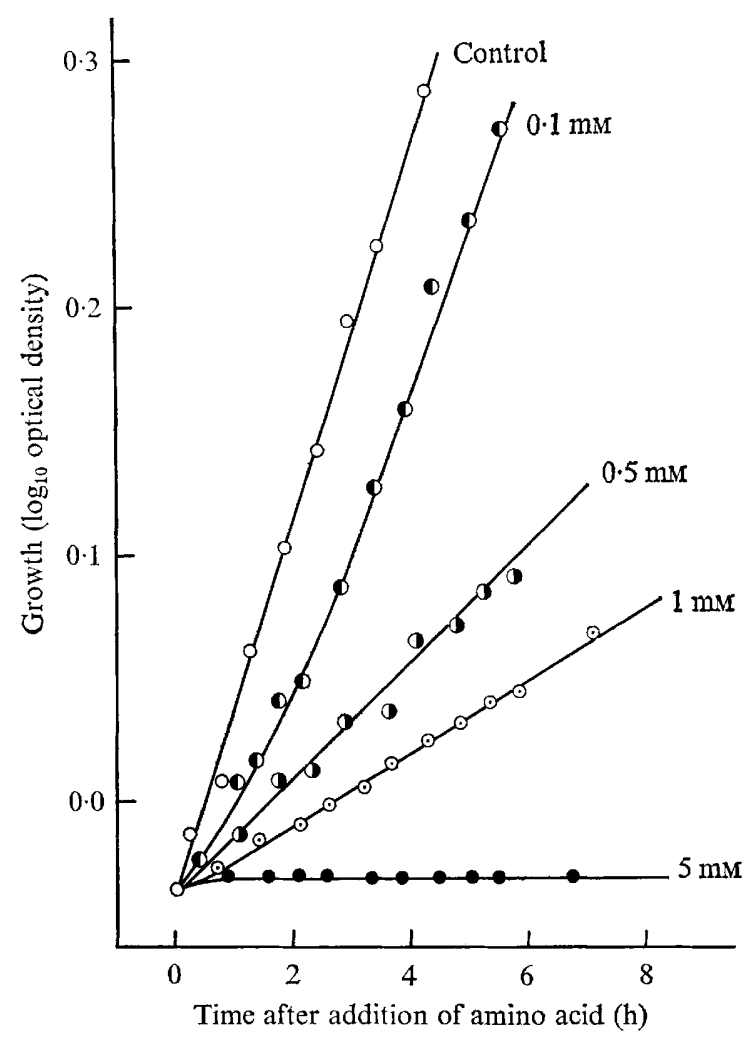

Fig. 2. Effect of several concentrations of L-phenylalanine on the growth of Methylococcus capsulatus. L-Phenylalanine was added to exponentially growing cultures at a cell density of $0.31 \mathrm{mg}$ dry wt bacteria $/ \mathrm{ml}$. The control received only water.

were, however, potent growth inhibitors at this concentration as were L-phenylalanine, L-histidine and to a lesser extent L-tyrosine and L-homoserine (Table I).

L-Leucine was selected as a typical non-inhibitory amino acid and tested at higher concentrations. When added to early exponential phase cultures at the usual cell density of $0.31 \mathrm{mg} / \mathrm{ml}, 5 \mathrm{~mm}-\mathrm{L}-\mathrm{leucine}$ depressed the growth rate by only $29 \%$, and Io mM by $67 \%$. The effect of high concentrations of L-leucine was dependent on the state of the culture at the time of addition of the acid. Thus ro mM-L-leucine was more inhibitory when added to cultures in the late exponential phase, but least inhibitory during early exponential growth. Growth did not occur if 10 mm-leucine was added during the lag phase.

Inhibition by threonine. Both L- and D-threonine depressed growth, even at $0.5 \mathrm{~mm}$, although the D isomer appeared to be more inhibitory than the L-form. Except at very high concentrations, L-threonine did not prevent growth, but caused an overall reduction of the growth rate, suggesting a reduction in the rate of biosynthesis of one or more essential metabolites (Fig. I). By contrast, D-threonine caused a progressive decrease of the growth rate until growth finally ceased several hours after the addition of the acid, indicating a different mode of action.

Inhibition by phenylalanine. L-Phenylalanine caused marked inhibition at $0.5 \mathrm{~mm}$ and, like L-threonine, caused a reduction of the exponential growth rate (Fig. 2). Unlike inhibition by threonine, that by phenylalanine was stereospecific. D-Phenylalanine had no effect on the growth rate of Methylococcus capsulatus even at $\mathrm{I} \cdot 0 \mathrm{mM}$. 


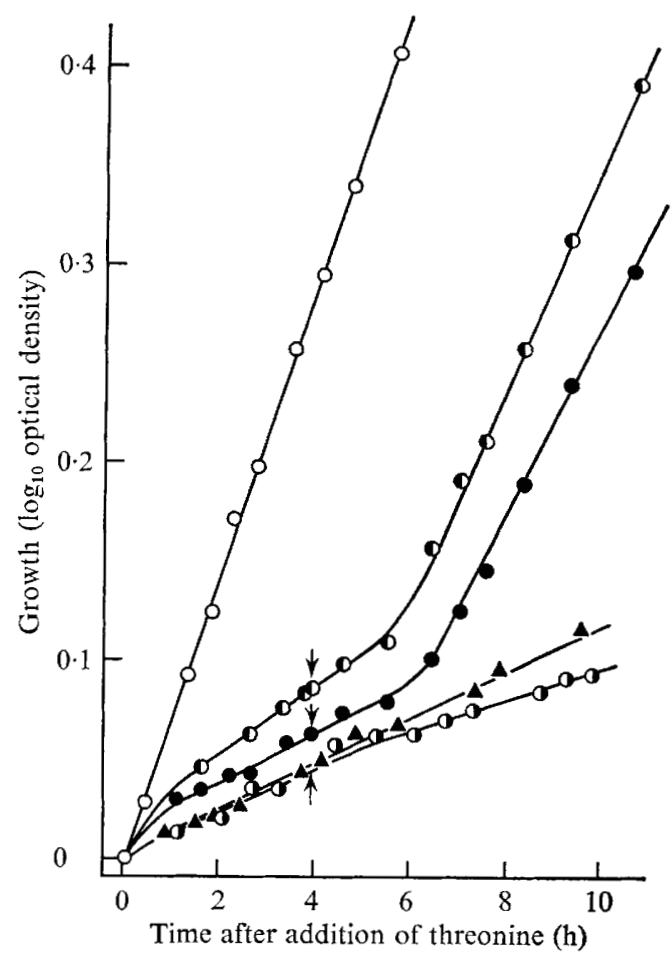

Fig. 3. Relief of threonine inhibition by lysine plus methionine and by methionine alone. Cultures $\boldsymbol{D}, \boldsymbol{\Delta}$ and received threonine at zero time. The control culture, $O$, received only water. After $4 \mathrm{~h}$, at the points marked by the arrows, culture received methionine; culture received lysine; culture received a mixture of both methionine and lysine; culture $\boldsymbol{\Delta}$ received no further additions. The final concentration of each amino acid was I mM.

Inhibition by L-histidine, L-tyrosine and L-homoserine. L-Histidine showed considerable toxicity at $0.5 \mathrm{~mm}$ and gave similar inhibition curves to those of $\mathrm{D}$-threonine. Thus $\mathrm{L}$-histidine at $\mathrm{I} \mathrm{mM}$ progressively reduced the growth rate until growth finally ceased 8 to $9 \mathrm{~h}$ after addition of the acid. L-Tyrosine and L-homoserine caused a reduction of the overall growth rate at I.O mM (Table I) and were thus recorded as growth inhibitors, although in comparison with the previous acids they were less toxic. Although L-tryptophan alone was not inhibitory, a mixture of tyrosine and tryptophan (each at $\mathrm{I} \cdot 0 \mathrm{mM}$ ) completely inhibited growth.

Relief of L-threonine inhibition by other members of the aspartate family. Simultaneous addition of methionine and lysine (each at I mM) to cultures which had received I $\mathrm{mM} \mathrm{L}$ threonine $4 \mathrm{~h}$ earlier led to an increase in the growth rate after a further $2.5 \mathrm{~h}$ (Fig. 3). Although the growth rate was not restored completely to normal under these conditions, it rose from I 5 to $20 \%$ to about $64 \%$ of the control value, following the addition of methionine and lysine. Methionine alone, however, also reversed threonine inhibition, raising the logarithmic growth rate to about $79 \%$ of normal, but lysine alone was completely ineffective as a relieving agent (Fig. 3).

Similar results were obtained under less drastic conditions in which threonine and test acid were added to growing cultures simultaneously but relief was then complete in the presence of methionine or the methionine-lysine mixtures, growth proceeding at the normal rate. Homoserine also proved to be an effective relieving agent, but neither lysine nor its immediate precursor, 2,6-diaminopimelic acid, had any relieving capacity. 


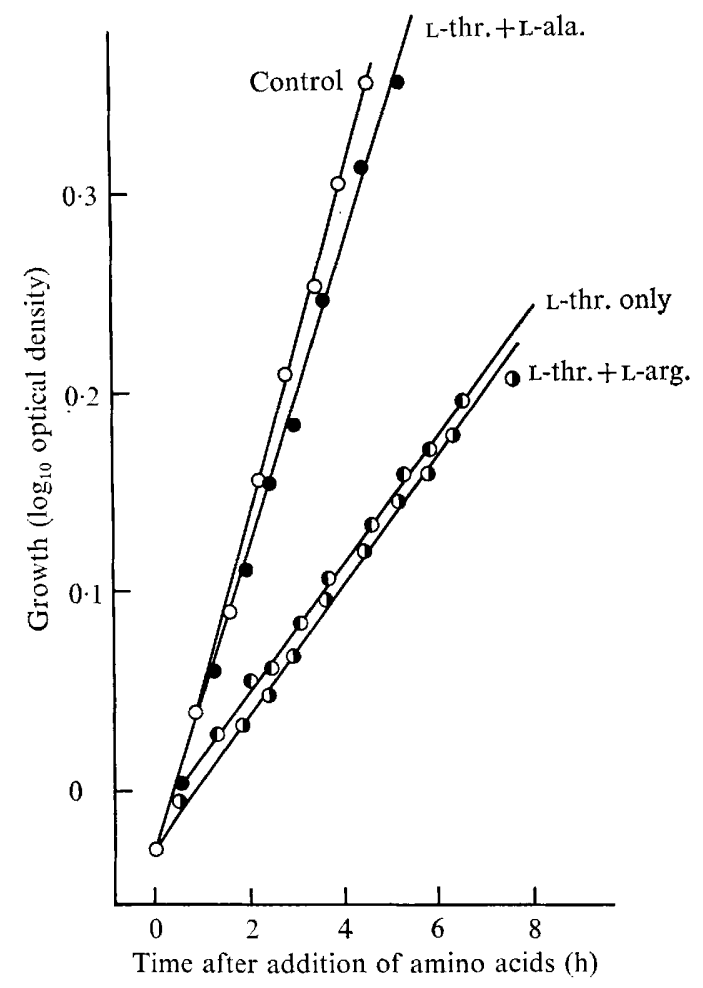

Fig. 4

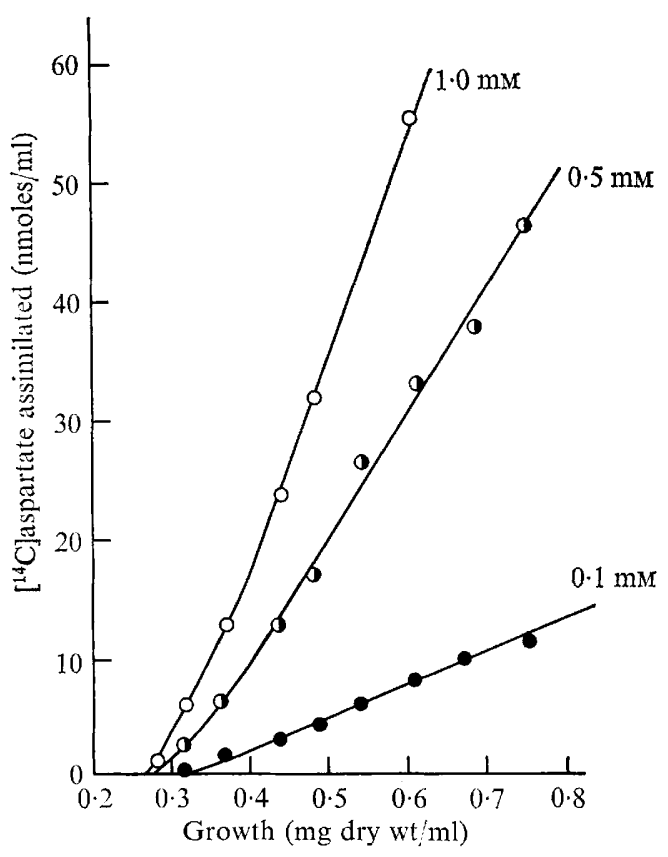

Fig. 5

Fig. 4. Effect of L-alanine and L-arginine on L-threonine inhibition in Methylococcus capsulatus. Amino acids were added to exponentially growing cultures at a cell density of $0.31 \mathrm{mg}$ dry wt cells $/ \mathrm{ml}$ to give a final concentration of I $\mathrm{mM}$. The control received only water.

Fig. 5. Incorporation of three concentrations of $\mathrm{L}-\left[\mathrm{U}-{ }^{14} \mathrm{C}\right]$ aspartate by exponentially growing Methylococcus cultures

Relief of threonine inhibition by metabolically unrelated amino acids. Inhibition by threonine was reversed by alanine (Fig. 4) and by valine, but arginine at the concentrations tested did not relieve inhibition (Fig. 4).

Assimilation of $\mathrm{L}-\left[\mathrm{U}^{14} \mathrm{C}\right]$ aspartic acid. $\mathrm{L}-\left[\mathrm{U}-{ }^{14} \mathrm{C}\right]$ aspartate added to logarithmically growing cultures was incorporated (Fig. 5) at rates which were approximately proportional to the concentration supplied (I06 $\mathrm{nmol} / \mathrm{mg} / \mathrm{ml}$ at $0.5 \mathrm{~mm} ; 27 \mathrm{nmol} / \mathrm{mg} / \mathrm{ml}$ at $0 . \mathrm{I} \mathrm{mM}$ ). Patel \& Hoare (197I) reported that Methylococcus capsulatus used aspartate as a nitrogen source, excreting aspartate-carbon into the medium as oxaloacetate and pyruvate. We did not test aspartate as a sole nitrogen source, but chromatography and autoradiography of the culture supernatant fraction after growth on $\mathrm{L}-\left[{ }^{14} \mathrm{C}\right]$ aspartate in the presence of inorganic nitrogen $\left(\mathrm{NH}_{4}^{+}\right)$gave only one radioactive spot, corresponding to aspartate. This suggests that aspartate was insignificant as a nitrogen source in the presence of inorganic nitrogen.

Analysis of Methylococcus capsulatus after assimilation of $\left[{ }^{14} \mathrm{C}\right]$ aspartate or $\left[{ }^{14} \mathrm{C}\right] \mathrm{methane}$ showed the ${ }^{14} \mathrm{C}$ to be in all bacterial fractions (Table 2, columns $a$ and $e$ ). The bulk of the label was in protein, lipid material and small molecules. Only about $5 \%$ of the label from aspartate was in nucleic acids, although chromatography of the nucleic acid hydrolysate showed at least $60 \%$ of the label in this fraction to be in pyrimidines, with an even distribu- 
Table 2. Fractionation of Methylococcus capsulatus after growth with $\mathrm{L}-\left[U-{ }^{14} C\right]$ aspartate or $\left[{ }^{14} C\right]$ methane

On reaching a cell density of $0.3 \mathrm{I} \mathrm{mg}$ dry $\mathrm{wt} / \mathrm{ml}$, cultures $(a)$ to $(d)$ received $\left[{ }^{14} \mathrm{C}\right]$ aspartate (I029.2 c.p.m./nmol) to give a final concentration of $0.5 \mathrm{~mm}$; cultures $(e)$ to $(g)$ received $\left[{ }^{14} \mathrm{C}\right]$ methane $(7 \mu \mathrm{Ci})$ (see Methods). Cultures $(b),(c)$ and $(d)$ also received 0.5 mM-unlabelled L-threonine, D-threonine or L-homoserine; and cultures $(f)$ and $(g)$ received $0.25 \mathrm{mM}$-L-threonine or $\mathrm{D}$-threonine respectively. Control cultures $(a)$ and $(e)$ received similar volumes of water. Cultures were harvested for fractionation on reaching approximately I $\mathrm{mg}$ dry wt/ml (late in the exponential phase).

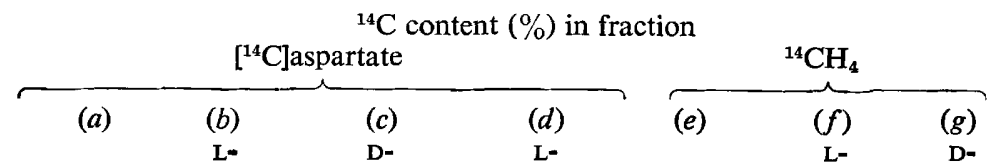

Fraction Control threonine threonine homoserine Control threonine threonine

Cold $5 \%$ TCA

$70 \%$ ethanol

Ethanol-ether

Hot $5 \%$ TCA

Residue (protein)

$\begin{array}{rrr}18 \cdot 9 & 39 \cdot 5 & 29 \cdot 8 \\ 33 \cdot 8^{*} & 22 \cdot 4 & 32 \cdot 9 \\ 1 \cdot 4 & 1 \cdot 4 & 0 \cdot 8 \\ 5 \cdot 4 & 6 \cdot 9 & 5 \cdot 4 \\ 40 \cdot 5 & 29 \cdot 8 & 31 \cdot 1\end{array}$

$38 \cdot 9$
$31 \cdot 3$
0.8
$4 \cdot 9$
$24 \cdot I$

$\begin{array}{rrr}8 \cdot 3 & 1 \mathrm{II} \cdot 2 & 1 \mathrm{II} \cdot 6 \\ 33 \cdot 8 & 36 \cdot \mathrm{I} & 32 \cdot 7 \\ 0 \cdot 8 & 0 \cdot 8 & 0 \cdot 6 \\ 22 \cdot 9 & 19 \cdot \mathrm{I} & 25 \cdot 8 \\ 34 \cdot 2 & 32 \cdot 8 & 29 \cdot 3\end{array}$

* Partition of the $70 \%$ ethanol fraction into aqueous and ether phases (Roberts et al. 1955) showed $54 \%$ of the ${ }^{14} \mathrm{C}$ in the ether phase (= lipid) and $46 \%$ in the aqueous phase (probably as protein).

Table 3. Composition of $\left[{ }^{14} \mathrm{C}\right]$ nucleic acids from Methylococcus capsulatus
\[ \begin{array}{cc}\text { after }\left[{ }^{14} \mathrm{C}\right] \text { aspartate assimilation } \\ \text { Compound } & { }^{14} \mathrm{C} \text { content }(\%) \\ \text { Adenine } & 10 \cdot 0 \\ \text { Guanine } & 1 \mathrm{I} \cdot 9 \\ \text { Cytosine+ cytidylic acid } & 30 \cdot 3 \\ \text { Uracil + uridylic acid } & 3 \mathrm{I} \cdot 6 \\ \text { Not positively identified } & 16 \cdot 2\end{array} \]

tion between uridylic and cytidylic acids (Table 3). Similar results were reported for the obligate chemolithotroph Thiobacillus neapolitanus strain c (Kelly, 1967) and suggest that the biosynthetic pathway for the synthesis of pyrimidines from aspartate, operative in heterotrophs such as Escherichia coli, also functions in obligate autotrophs and methylotrophs.

Hydrolysis of the protein (Table 4 , column $a$ ) showed ${ }^{14} \mathrm{C}$ from aspartate to be widely distributed among all the amino acids identified, including threonine and lysine. The methionine-valine and phenylalanine-leucine-isoleucine spots were not further resolved.

Effect of $\mathrm{L}$ - and $\mathrm{D}$-threonine and $\mathrm{L}$-homoserine on $\left[{ }^{14} C\right]$ aspartate assimilation. Addition of any one of these compounds at subinhibitory concentrations resulted in a reduced flow of ${ }^{14} \mathrm{C}$ from aspartate into protein, the 'excess' remaining in the soluble pools of the cell' (cold TCA fraction), presumably as unchanged aspartate and Krebs' cycle intermediates (Table 2). This effect was most noticeable with L-homoserine, which reduced ${ }^{14} \mathrm{C}$ incorporation into the protein to about $60 \%$ of the control level, suggesting that exogenous homoserine can replace or supplement cellular synthesis of this compound, which is a precursor of threonine, isoleucine and methionine. Furthermore, analysis of the hydrolysed protein showed that ${ }^{14} \mathrm{C}$ incorporation into threonine was reduced by almost $75 \%$ when cultures were supplemented with L-homoserine, and by $68 \%$ when exogenous L-threonine was supplied, but by less than $10 \%$ in the presencetof $\mathrm{D}$-threonine (Table 4 ). Corresponding reductions might be expected'in methionine and isoleucine, although these compounds were not isolated for assay. ${ }^{14} \mathrm{C}$ levels 
Table 4. Distribution of ${ }^{14} \mathrm{C}$ in Methylococcus capsulatus protein after incorporation of $\left[{ }^{[4} \mathrm{C}\right]$ aspartate or $\left[{ }^{14} \mathrm{C}\right]$ methane by growing cultures (see Table 2)

${ }^{14} \mathrm{C}$ content $(\%)$ in chromatogram spots

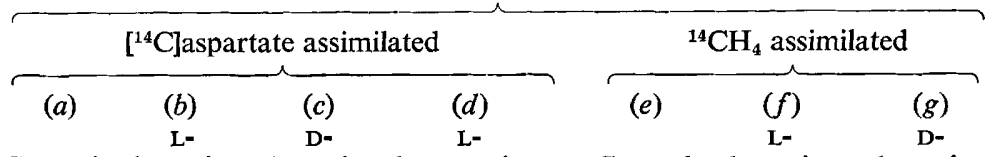

Identity of compound Control threonine threonine homoserine Control threonine threonine

Origin
Cysteine
Aspartate
Glutamate
Serine+glycine
Threonine
Alanine
Tyrosine
Lysine
Arginine
Proline
Methionine+valine
Isoleucine+leucine
+phenylalanine
Unknowns

\begin{tabular}{rrrr}
0.2 & 0.5 & 0.4 & 0.8 \\
0.7 & \multicolumn{1}{c}{-1} & - & \multicolumn{1}{c}{-} \\
17.7 & 17.8 & 19.2 & 19.3 \\
15.7 & 19.6 & 17.7 & 18.3 \\
8.9 & 9.0 & 7.8 & 9.7 \\
7.1 & 2.7 & 6.4 & 1.8 \\
5.3 & 13.3 & 13.2 & 10.8 \\
0.3 & - & - & - \\
8.5 & 10.5 & 5.5 & 8.4 \\
7.7 & 5.2 & 5.1 & 5.9 \\
6.4 & 7.9 & 7.5 & 8.2 \\
3.4 & 3.3 & 3.3 & 2.1 \\
16.1 & 10.2 & 13.1 & 12.6 \\
2.0 & - & 0.8 & 2.1
\end{tabular}

\begin{tabular}{|c|c|c|}
\hline 0.44 & $0 . I$ & 0.7 \\
\hline 0.88 & 0.4 & 0.6 \\
\hline $8 \cdot 2$ & $9 \cdot \mathbf{I}$ & $8 \cdot 2$ \\
\hline II O & $11 \cdot 9$ & 12.8 \\
\hline $6 \cdot 7$ & $8 \cdot 8$ & $7 \cdot 3$ \\
\hline $3 \cdot 2$ & $I \cdot 3$ & 3.5 \\
\hline $9 \cdot I$ & $9 \cdot 6$ & 8.9 \\
\hline $4 \cdot 2$ & $4 \cdot 6$ & $4 \cdot 2$ \\
\hline 8.9 & 9.9 & 8.8 \\
\hline $8 \cdot 6$ & 5.4 & $6 \cdot 1$ \\
\hline $5^{\circ} 0$ & $6 \cdot 3$ & $5 \cdot I$ \\
\hline $7 \cdot 6$ & $8 \cdot \mathrm{I}$ & 8.6 \\
\hline $24 \cdot 8$ & $23 \cdot 6$ & $23 \cdot 3$ \\
\hline $\mathrm{I}^{\cdot}$ & $1 \cdot 0$ & $2 \cdot 2$ \\
\hline
\end{tabular}

Table 5. Fractionation of Methylococcus capsulatus after $\mathrm{L}-\left[\mathrm{U}-{ }^{14} \mathrm{C}\right]$ homoserine assimilation

On reaching a cell density of $0.31 \mathrm{mg}$ dry wt bacteria $/ \mathrm{ml}, \mathrm{L}-\left[\mathrm{U}-{ }^{14} \mathrm{C}\right]$ homoserine $(406 \cdot 3$ c.p.m./ nmol) was added to exponentially growing cultures to give a final concentration of $0.1 \mathrm{mM}$. Cultures $(b)$ and $(c)$ also received $0^{\circ}$ I mM-unlabelled L-threonine or D-threonine, the control $(a)$ receiving a similar volume of water. Cultures were harvested for fractionation on reaching approximately $\mathrm{I} \mathrm{mg}$ dry wt cells $/ \mathrm{ml}$.

\begin{tabular}{ccc}
\multicolumn{3}{c}{${ }_{(a)}^{14} \mathrm{C}$ content $(\%)$ in fractions } \\
$\begin{array}{c}\left.{ }^{14} \mathrm{C}\right] \text { homoserine } \\
\text { control }\end{array}$ & $\begin{array}{c}\left({ }^{14} \mathrm{C}\right) \\
+\mathrm{L} \text {-threonine }\end{array}$ & $\begin{array}{c}(c) \\
{\left[{ }^{14} \mathrm{C}\right] \text { homoserine }} \\
+ \text { D-threonine }\end{array}$ \\
8.6 & 10.5 & $10 \cdot 2$ \\
24.3 & 27.5 & $22 \cdot 1$ \\
0.2 & 0.2 & 0.1 \\
2.6 & 2.5 & 2.0 \\
64.3 & 59.3 & 65.6
\end{tabular}

in other amino acids did not differ significantly from the control, except for alanine, which showed a significant increase in activity in all cases.

Effect of $\mathrm{L}$-threonine and $\mathrm{D}$-threonine on ${ }^{14} \mathrm{CH}_{4}$ assimilation. The distribution of ${ }^{14} \mathrm{C}$ among the cell fractions was similar in organisms grown on ${ }^{14} \mathrm{CH}_{4}$ with or without L- or D-threonine (Table 2, columns $e, f$ and $g$ ). When cultures were grown on ${ }^{14} \mathrm{CH}_{4}$ in the presence of unlabelled L-threonine, the ${ }^{14} \mathrm{C}$ content of threonine in the protein was reduced by $60 \%$ (Table 4, column $f$ ). The amount of methane-carbon converted to threonine during growth with exogenous D-threonine was not significantly different from the control. Radioactivity in all other amino acid spots remained in both cases at the control level, with no increase of activity in alanine.

Assimilation of $\mathrm{L}_{-}\left[U_{-}{ }^{14} \mathrm{C}\right]$ threonine and the effect of isoleucine. Incorporation of exogenous threonine was considerably greater than for aspartic acid at comparable concentrations (e.g. I $50.5 \mathrm{nmol} / \mathrm{mg} / \mathrm{ml}$ at $0.1 \mathrm{mM}$ ), but again incorporation was concentration-dependent. 
Table 6. Distribution of ${ }^{14} \mathrm{C}$ in Methylococcus capsulatus protein after $\mathrm{L}-\left[U_{-}{ }^{14} \mathrm{C}\right]$ homoserine incorporation by growing cultures

\begin{tabular}{|c|c|c|c|}
\hline \multirow[b]{2}{*}{$\begin{array}{l}\text { Identity of } \\
\text { compound }\end{array}$} & \multicolumn{3}{|c|}{${ }^{14} \mathrm{C}$ content $(\%)$ in chromatogram spots } \\
\hline & $\begin{array}{l}(a) \\
{\left[{ }^{14} \mathrm{C}\right] \text { homoserine }} \\
\text { control }\end{array}$ & $\begin{array}{l}(b) \\
{\left[{ }^{14} \mathrm{C}\right] \text { homoserine }} \\
\text { +L-threonine }\end{array}$ & $\begin{array}{c}(c) \\
{\left[{ }^{14} \mathrm{C}\right] \text { homoserine }} \\
+\mathrm{D} \text {-threonine }\end{array}$ \\
\hline $\begin{array}{l}\text { Threonine } \\
\text { Isoleucine } \\
\text { Methionine+ } \\
\text { decomposition } \\
\text { products }\end{array}$ & $\begin{array}{l}50 \cdot 5 \\
47 \cdot I\end{array}$ & $\begin{array}{l}47 \cdot I \\
48 \cdot 6\end{array}$ & $\begin{array}{l}59 \cdot 2 \\
36 \cdot 9\end{array}$ \\
\hline
\end{tabular}

Analysis of the protein fraction of cells grown with $0.5 \mathrm{mM} \mathrm{L}-\left[{ }^{14} \mathrm{C}\right]$ threonine showed significant radioactivity only in threonine $(59 \%)$ and isoleucine $(4 \mathrm{I} \%)$, implying that, as in heterotrophs, threonine is a precursor of isoleucine synthesis, and that exogenous threonine can be used by the cell for this synthesis. But when cultures were grown with a mixture of $0.2 \mathrm{mM} \mathrm{L}-\left[{ }^{14} \mathrm{C}\right]$ threonine and $0.6 \mathrm{~mm}$-unlabelled L-isoleucine, $98.5 \%$ of the radioactivity remained in threonine, suggesting preferential use of exogenous isoleucine and inhibition of biosynthesis of isoleucine from threonine in the cell under these conditions.

Assimilation of $L_{-}\left[U_{-}{ }^{14} C\right]$ homoserine. Incorporation of $\left[{ }^{14} \mathrm{C}\right]$ homoserine by logarithmically growing cultures was only examined at one concentration ( $0.1 \mathrm{mM})$, but incorporation of this amino acid was at least as great as that of L-threonine at this concentration ( $182.5 \mathrm{nmol}$ homoserine $/ \mathrm{mg} / \mathrm{ml}$ ). Fractionation of cells after $\left[{ }^{14} \mathrm{C}\right]$ homoserine assimilation showed most of the ${ }^{14} \mathrm{C}$ to be in the protein fraction, with smaller amounts in lipid ( $70 \%$ ethanol soluble) and the cold TCA fraction (Table 5, column $a$ ).

Subsequent analysis of the protein fraction was complicated by the decomposition of methionine to methionine sulphoxide, methionine sulphone and a few minor products, under the conditions of protein hydrolysis employed. Preliminary analyses were therefore made of the protein hydrolysates (both peroxidized and untreated) from cells grown with either ${ }^{35} \mathrm{SO}_{4}{ }^{2-}, \mathrm{L}-\left[{ }^{14} \mathrm{C}\right]$ homoserine, or a mixture of both. The chromatographic positions of all nonvolatile sulphur-containing amino compounds of the Methylococcus protein was thus determined. Less than one-third ( 29 to $30 \%$ ) of the total ${ }^{35} \mathrm{~S}$ on the chromatograms represented methionine and its decomposition products, compared with two-thirds for a similar analysis of Escherichia coli protein (Roberts et al. 1955). Increase in radioactivity in some chromatogram spots from cells grown on both ${ }^{35} \mathrm{SO}_{4}{ }^{2-}$ and $\left[{ }^{14} \mathrm{C}\right]$ homoserine, and a comparison with the single-labelled controls enabled us to confirm that homoserine-carbon was converted to methionine. The results of subsequent analyses (Table 6, column $a$ ) showed that most of the labelled homoserine incorporated was converted to threonine $\left(50 \cdot 5 \%\right.$ of total $\left.{ }^{14} \mathrm{C}\right)$ and isoleucine $\left(47 \cdot 1 \%\right.$ of $\left.{ }^{14} \mathrm{C}\right)$, with only $2 \cdot 4 \%$ recovered in methionine and its decomposition products.

Effect of $\mathrm{L}-$ threonine and $\mathrm{D}$-threonine on $\mathrm{L}-\left[U_{-}{ }^{14} C\right]$ homoserine assimilation. Gross labelling patterns in organisms grown in the presence of equimolar amounts (O. I mM) of L- $\left[{ }^{14} \mathrm{C}\right]$ homoserine and unlabelled L-threonine or D-threonine were similar (Table 5). Neither amino acid altered significantly the amount of ${ }^{14} \mathrm{C}$ consumed, but L-threonine diminished ${ }^{14} \mathrm{C}$ in protein by $5 \%$ (Table 5). Analysis of hydrolysed protein (Table 6) showed that exogenous L-threonine did not affect the ${ }^{14} \mathrm{C}$ distribution between threonine and isoleucine, but an increase of label in methionine was observed. D-Threonine, however, produced a significant change in the ${ }^{14} \mathrm{C}$ distribution pattern, $59 \cdot 2 \%$ of the ${ }^{14} \mathrm{C}$ being located in threonine and only $36 \cdot 9 \%$ in 
isoleucine, again with an increase in methionine. Although L-threonine only produced slight changes at the concentration employed, the small drop in total labelled protein is consistent with the view that exogenous threonine provides the cell with an alternative supply of threonine, reducing the rate of cellular synthesis of this compound from homoserine. The use of both exogenous and endogenous L-threonine for isoleucine synthesis would not be expected to affect the distribution of homoserine-carbon between threonine and isoleucine in the protein. Alteration of this distribution ratio by $D$-threonine further indicates a different metabolic response by Methylococcus capsulatus to the $\mathrm{D}$ isomer.

Incorporation of $\mathrm{L}-\left[U_{-}{ }^{14} C\right]$ glutamic acid and $\mathrm{L}-\left[U_{-}{ }^{14} C\right]$ lysine. Both $\left[{ }^{14} \mathrm{C}\right]$ glutamate and $\left[{ }^{14} \mathrm{C}\right]$ lysine were incorporated when fed separately (at $0.05 \mathrm{mM}$ ) to exponentially growing cultures of Methylococcus capsulatus. Uptake rates were $2 \mathrm{I} \cdot 8 \mathrm{nmol}$ glutamate $/ \mathrm{mg} / \mathrm{ml}$ and $3.5 \mathrm{nmol}$ lysine $/ \mathrm{mg} / \mathrm{ml}$. Analysis of the protein of organisms grown with $\left[{ }^{14} \mathrm{C}\right]$ glutamate showed half $(48 \cdot 7 \%)$ of the protein- ${ }^{14} \mathrm{C}$ as unchanged glutamate, with the remainder equally distributed between the glutamate-derivates, arginine (25.5\% of total) and proline $(24.2 \%)$, and $\mathrm{I} \cdot 6 \%$ in an unidentified 'ghost' spot. Analysis of protein from cells grown with $\left[{ }^{14} \mathrm{C}\right]-$ lysine showed all radioactivity to be in lysine.

Incorporation of $\mathrm{L}-\left[U-{ }^{14} C\right]$ phenylalanine and $\mathrm{L}-\left[\right.$ methylene $\left.-{ }^{14} C\right]$ tryptophan. Both these amino acids were incorporated when supplied at subinhibitory concentrations to growing Methylococcus capsulatus. Uptake rates at $0.05 \mathrm{mM}$ were I $2 \mathrm{nmol}$ phenylalanine $/ \mathrm{mg} / \mathrm{ml}$ and $50 \mathrm{nmol}$ tryptophan $/ \mathrm{mg} / \mathrm{ml}$.

\section{DISCUSSION}

No previous systematic investigation has been published concerning the utilization and mode of action of toxic amino acids by Methylococcus capsulatus. Our results confirm the observation by Eroshin, Harwood \& Pirt (I968) that some amino acids depress the growth of $M$. capsulatus, but in our experiments marked inhibition of growing cultures was observed only with six amino acids, including the four protein-L-amino acids, threonine, phenylalanine, tyrosine and histidine. The greater number of amino acids previously found to be inhibitory (Eroshin, Harwood \& Pirt, 1968) can be ascribed to the greater sensitivity of organisms in the lag phase than of organisms in growing cultures to inhibition. This was exemplified in our study by inhibition of lag phase organisms by leucine, which was relatively less toxic to growing organisms. Our experiments also provide the first demonstration that a number of amino acids can be assimilated and in some cases undergo extensive secondary metabolism in $M$. capsulatus.

Toxicity of amino acids is not uncommon, especially among the autotrophs (Leadbetter \& Foster, I958; Kelly, I969a, I97I ; Rittenberg, I969; Lu, Matin \& Rittenberg, I97I), and in general has been attributed to imbalance of amino acid metabolism. In Thiobacillus neapolitanus, inhibition by phenylalanine was attributed to its acting as an end-product inhibitor of the first enzyme of the branched pathway for aromatic amino acid biosynthesis (Kelly, $1969 c$ ). In consequence the organism could not synthesize sufficient tryptophan and tyrosine for normal growth (Kelly, I $969 a, b$ ). Inhibition of some bacteria by other amino acids probably also results from 'starvation' of the organisms for essential amino acids as a consequence of end-product inhibition of early reactions of multiple-product branched pathways.

An explanation of the possible mode of action of the toxic amino acids, threonine, phenylalanine and tyrosine is thus available. The former could depress lysine and methionine biosynthesis by inhibiting aspartokinase and homoserine dehydrogenase, enzymes of the branched pathway also leading to threonine (Truffa-Bachi \& Cohen, 1968; Cohen, Stanier \& Le Bras, 1969). Phenylalanine and tyrosine could inhibit an early stage in the aromatic 
amino acid pathway, thus depressing synthesis of tryptophan as well as that of phenylalanine and tyrosine (Gibson \& Pittard, I968; Kelly, 1971).

Such explanations presuppose the occurrence of established pathways in Methylococcus capsulatus. Our incorporation experiments with ${ }^{14} \mathrm{C}$-labelled substrates suggest this assumption to be valid for the aspartate pathway, because: (i) aspartate-carbon appeared in members of the aspartate family; (ii) homoserine-carbon entered only threonine, isoleucine and methionine; (iii) threonine-carbon entered only threonine and isoleucine; (iv) $\left[{ }^{14} \mathrm{C}\right]$ lysine appeared unchanged in protein. Aspartate-carbon also entered glutamate, proline and arginine, but this probably depended on aspartate being converted to $\alpha$-oxoglutarate after entering the tricarboxylic acid cycle as oxaloacetate and pyruvate. Glutamate would arise from $\alpha$-oxoglutarate and our separate observations with $\left[{ }^{14} \mathrm{C}\right]$ glutamate showed it to be the precursor only of proline and arginine.

Threonine might inhibit growth by inhibiting early steps of the aspartate pathway, thus depressing synthesis of methionine, lysine, or both. If this were so, growth inhibition might be relieved by methionine and lysine. As lysine was ineffective and methionine effective in reversing inhibition it is possible that threonine acted only on homoserine dehydrogenase, thus not affecting lysine formation, but depressing methionine synthesis. This possibility is being investigated with enzyme preparations, but reversal of threonine inhibition by valine and alanine suggests that a less simple explanation for methionine reversal may apply. A probability is that threonine entry into the cell was depressed by other amino acids, competing for a non-specific transport system, such as occurs in Thiobacillus neapolitanus (Kelly, $1969 b$ ) and some other organisms (Jones, I963; Brown, I970), and which we shall report in a subsequent paper (M. Eccleston \& D. P. Kelly, in preparation).

Inhibition by L-histidine and D-threonine has not yet been further studied. The lowering by $\mathrm{D}$-threonine of ${ }^{14} \mathrm{C}$-incorporation from $\mathrm{L}-\left[{ }^{14} \mathrm{C}\right]$ threonine into isoleucine suggests that $\mathrm{D}$-threonine might be converted to isoleucine, thus 'diluting' the ${ }^{14} \mathrm{C}$-label from $\mathrm{L}-\left[{ }^{14} \mathrm{C}\right]-$ threonine. This could occur if the threonine dehydratase of Methylococcus capsulatus is of low stereospecificity. Toxicity of D-threonine could be due to a feedback effect resembling that of L-threonine, but could result from interference with the activation of L-threonine prior to protein synthesis. Failure of D-threonine to alter the $\left[{ }^{14} \mathrm{C}\right]$ threonine content of protein in organisms grown on $\left[{ }^{14} \mathrm{C}\right]$ methane suggests that $\mathrm{D}$-threonine does not enter protein but the possibility of a low level of incorporation has not been eliminated.

M.E. acknowledges a Science Research Council Studentship. We thank Dr C. F. Thurston for a gift of $\mathrm{L}-\left[{ }^{14} \mathrm{C}\right]$ homoserine.

\section{REFERENCES}

Alfem, M. I. H. (1970). Oxidation of inorganic nitrogen compounds. Annual Review of Plant Physiology 2x, $67-90$.

Brown, K. D. (1970). Formation of aromatic amino acid pools in Escherichia coli K I2. Journal of Bacteriology 104, $177-\mathrm{I} 88$.

Cohen, G. N., Stanier, R. Y. \& Le Bras, G. (1969). Regulation of the biosynthesis of amino acids of the aspartate family in coliform bacteria and pseudomonads. Journal of Bacteriology 99, 79I-80I.

DAVIES, J. W. \& CoCKING, E. C. (I966). Liquid scintillation counting of ${ }^{14} \mathrm{C}$ and ${ }^{3} \mathrm{H}$ samples using glass fibre or filter paper discs. Biochimica et biophysica acta 15 5, $5 \mathrm{I}$ I-5I3.

Eroshin, V. K., HaRwood, J. H. \& PIRT, S. J. (I968). Influence of amino acids, carboxylic acids and sugars on the growth of Methylococcus capsulatus on methane. Journal of Applied Bacteriology 3r, 560-567.

Foster, J. W. \& DAVIS, R. H. (1966). A methane-dependent coccus, with notes on classification and nomenclature of obligate, methane-utilizing bacteria. Journal of Bacteriology 9r, 1924-I93I.

Gibson, F. \& PitTard, J. (1968). Pathways of biosynthesis of aromatic amino acids and vitamins and their control in microorganisms. Bacteriological Reviews 32, 465-492. 
Johnson, C. L. \& VishniaC, W. (1970). Growth inhibition in Thiobacillus neapolitanus by histidine, methionine, phenylalanine and threonine. Journal of Bacteriology ro4, 1145-1 150.

JONES, O.T. G. (1963). The accumulation of amino acids by fungi, with particular reference to the plant parasitic fungus Botrytis fabae. Journal of Experimental Botany 14, 399-4II.

KeLLY, D. P. (1967). The incorporation of acetate by the chemoautotroph Thiobacillus neapolitanus strain C. Archiv für Mikrobiologie 58, 99-116.

KeLLY, D. P. (1969a). Regulation of chemoautotrophic metabolism. I. Toxicity of phenylalanine to Thiobacilli. Archiv für Mikrobiologie 69, 330-342.

KeLLY, D. P. (1969b). Regulation of chemoautotrophic metabolism. II. Competition between amino acids for incorporation into Thiobacillus. Archiv für Mikrobiologie 69, 343-359.

KeLLY, D. P. (1969c). Regulation of chemoautotrophic metabolism. III. DAHP synthetase in Thiobacillus neapolitanus. Archiv für Mikrobiologie 69, 360-369.

KeLLY, D. P. (I97I). Autotrophy: concepts of lithotrophic bacteria and their organic metabolism. Annual Review of Microbiology 25, 177-210.

KeMP, M. B. (1972). The hexose phosphate synthetase of Methylococcus capsulatus. Biochemical Journal (in the press).

KemP, M. B. \& QuAYLE, J. R. (I966). Microbial growth on $C_{1}$ compounds: incorporation of $C_{1}$ units into allulose phosphate by extracts of Pseudomonas methanica. Biochemical Journal 99, 4I-48.

Lawrence, A. J., Kemp, M. B. \& Quayle, J. R. (1970). Synthesis of cell constituents by methane-grown Methylococcus capsulatus and Methanomonas methanooxidans. Biochemical Journal II6, 63I-639.

LEADBETTER, E. R. \& FosteR, J. W. (1958). Studies on some methane utilizing bacteria. Archiv für Mikrobiologie 30, $9 \mathrm{I}-\mathrm{I} \mathrm{I} 8$.

Lu, M. C., Matin, A. \& Rittenberg, S. C. (197I). Inhibition of growth of obligately chemolithotrophic thiobacilli by amino acids. Archiv für Mikrobiologie 79, 354-366.

Patel, R. N. \& Hoare, D. S. (197I). Physiological studies of methane and methanol-oxidizing bacteria: oxidation of C-I compounds by Methylococcus capsulatus. Journal of Bacteriology ro7, 187-192.

Patel, R., HoARe, D. S. \& TAYLOR, B. F. (I969). Biochemical basis for the obligate C-I dependence of Methylococcus capsulatus. Bacteriological Proceedings, $70 \mathrm{P}$.

QUAYLE, J. R. (1969). Microbial growth on $\mathrm{C}_{1}$ compounds. Process Biochemistry 4, 25-29.

Ribbons, D. W., HaRrison, J. E. \& WadzinsKi, A. M. (I970). Metabolism of single carbon compounds. Annual Review of Microbiology 24, I35-I 58.

RITTENBERG, S. C. (I969). The roles of exogenous organic matter in the physiology of chemolithotrophic bacteria. Advances in Microbial Physiology 3, 159-196.

Roberts, R. B., Abelson, P. H., Cowie, D. B., Bolton, E. J. \& Britten, R. J. (1955). Studies on biosynthesis in Escherichia coli. Publication of the Carnagie Institution 607. Washington D.C.: Carnegie Institution.

SMith, A. J., London, J. \& STANIER, R. Y. (1967). Biochemical basis of obligate autotrophy in blue-green algae and thiobacilli. Journal of Bacteriology 94, 972-983.

SмIтH, I. (1960). Chromatographic and Electrophoretic Techniques, vol. I. London: W. Heinemann.

Truffa-BACH, P. \& CoHEN, G. N. (I968). Some aspects of amino acid biosynthesis in microorganisms. Annual Review of Biochemistry 37, 79-108.

Whittenbury, R., Phillips, K. C. \& Wilkinson, J. F. (1970). Enrichment, isolation and some properties of methane-utilizing bacteria. Journal of General Microbiology 6r, 205-218.

WILKINSON, J. F. (1971). Hydrocarbons as a source of single cell protein. In Microbes and Biological Productivity. Symposium of the Society for General Microbiology 2I, 15-46. 